University of Warwick institutional repository: http://go.warwick.ac.uk/wrap This paper is made available online in accordance with publisher policies. Please scroll down to view the document itself. Please refer to the repository record for this item and our policy information available from the repository home page for further information.

To see the final version of this paper please visit the publisher's website. Access to the published version may require a subscription.

Author(s): Shaun Breslin

Article Title: Why Growth Equals Power and Why it Shouldn't: The Case of China's Global Economic Role

Year of publication: 2008

Link to published version: http://dx.doi.org/10.1080/17516230701835906

Publisher statement: None 


\title{
Why growth equals power - and why it shouldn't: Constructing Visions of China
}

\author{
Shaun Breslin, University of Warwick, UK
}

\begin{abstract}
When discussing the "success" of China's transition from socialism, there is a tendency to focus on growth figures as an indication of performance. Whilst these figures are indeed impressive, we should not confuse growth with development and assume that the former necessarily automatically generates the latter. Much has been done to reduce poverty in China, but the task is not as complete as some observers would suggest; particularly in terms of access to health, education and welfare, and also in dealing with relative (rather than absolute) depravation and poverty. Visions of China have been constructed that exaggerate Chinese development and power in the global system partly to serve political interests, but partly due to the failure to consider the relationship between growth and development, partly due to the failure to disaggregate "who gets what" in China, and partly due to the persistence of international conceptions of globalised production, trade, and financial flows.
\end{abstract}

Keywords: China, growth, development, GDPism

It would be strange if China's economic performance had not generated massive international attention. Of course China is not the first country to emerge from relative backwardness with sustained high growth rates, but in many ways it is the sheer scale of the Chinese case that marks it out for special attention; the sheer size of the economy, the number and value of exports and the resulting trade surplus, the foreign currency holdings, the massive flows of inward investment and more recently, the growth of outward investment all combine to ensure that virtually no country has been unaffected by what has happened in China.

But while the focus on China is entirely understandable, some of the conclusions of studies of Chinese growth are not always as easy to comprehend. In particular, while the overall size and scale of economic activity in China are clearly 
important, focussing on growth and the aggregate national situation -'GDPism' ${ }^{1}$ tends to confuse growth with development and can result in the domestic distribution of the fruits of growth being ignored. It also can be used to exaggerate the extent of Chinese power in the global political economy - both present and projected.

As such, the critique of GDPism contains two main elements. The first points to the uneven developmental consequences of growth in China and the extent of residual poverty - issues that are well understood by not only students of Chinese politics but also the Chinese leadership, and thus will be covered with relative brevity. The second asks why it is that visions and understandings have been constructed that tend to exaggerate China's wealth and power, and to outline the consequences of these constructed images for policy making?

The answer is partly found in the domestic policy making environments of countries responding to Chinese economic growth. Manoeuvring to compete for the benefits that China's future economic wealth will generate (often fired by the lobbying and initiatives of business interests) ${ }^{2}$ results in constructed understandings of what China will become in the future dictating policy towards China today. Or put another way, expectations of future power condition current policy to the extent that China has been cognitively externally empowered. But the answer is also partly found in the dominance of theoretical approaches that focus on the nation state as the unit of analysis.

Whilst China is clearly important and likely to become ever more so, a different 'knowledge' of China's power and position in the global order is generated

$1 \quad$ I use the term GDPism as this paper was first presented at the Third East Asian Social Policy Research Network International Conference on 'GDPism and Risk: Challenges for Social Development and Governance in East Asia’ at the University of Bristol’s Centre for East Asian Studies in July 2006.

2 I discussed how UK policy towards China was influenced by notions of international competition to access the Chinese market in Breslin (2004). 
by deploying different theoretical approaches; approaches that (re)connect the domestic with the international, that acknowledge the fragmentation of production (and trade) in a post-fordist globalised economy; and move away from an understanding of states as the sole repositories of power in the global political economy.

\section{Different Visions of China}

Popular visions and understandings of China vary significantly, so any attempt to provide an overview can only deal in challengeable overgeneralizations. With this caveat in mind, we can observe that there are four major strands to popular visions and understandings of China today - the first two of which are the most important in shaping popular understandings, and in some places, policy towards China. The first focuses on China as a repressive and coercive authoritarian political system; perhaps no longer a 'Stalinist dictatorship', but certainly 'not free'. The campaigning work of Human Rights and religious groups and those promoting Tibetan independence, relatively frequent investigative media reports, and the annual US report on 'Human Rights Practices ${ }^{3}$ all ensure that the issue remains on the international agenda - albeit with a rather lower profile today than in the days after $4^{\text {th }}$ June 1989 . This focus on human rights frequently clearly irks many in China - and not just party-state officials - but whilst it may be unpalatable, it is important to accept that this is indeed a strong basis of many external visions and understandings of China. As will be discussed in more detail below, perceptions of China's rise are very much coloured by concerns about the type of political system that is rising.

3 These reports can be found on http://www.state.gov/g/drl/rls/hrrpt. Since 1998, the Chinese authorities have responded by issuing their own annual report on 'The Human Rights Record of the United States' - see http://news.xinhuanet.com/english/2007-

03/08/content_5817027.htm 
Until fairly recently, the rights and freedom discourse was perhaps the dominant source of perceptions of China. The vote in the US congress over whether to renew China’s Most Favoured Nation status provided an annual opportunity for high profile discussion, as did the annual resolutions condemning China's human rights record at the UN Human Rights Commission. But while such a resolution came within one vote of being adopted in 1995, the EU stopped tabling resolutions in 1997 followed by the US in 2002. In addition, the need for an annual debate and vote in Washington came to an end in 1999 when China was awarded Permanent Normal Trade Relations as part of the process of ensuring WTO entry.

Such an apparent downgrading of the significance of human rights is, for some, a result of the increasing significance of the second major image of China - a vision of a rich and economically (at least) powerful China that provides new challenges to the existing balance of power in the global order. Whilst what China might become at some point in the future is the focus for some, there is already a school of thought that conceives of China as already having great power in the global political economy, and a larger school that suggests that the assumption of power is inevitable. ${ }^{4}$ It might be tempting to dismiss these works as sensationalist, but this view of China has resonance amongst a public who see media stories of the world's biggest ship bringing 11,000 containers of Christmas supplies from China to Europe 'to the relief of children, parents and shopkeepers everywhere - but to the despair of European manufacturers' (Vidal 2006). And at times, the fear that this new 'manufacturing superpower' is leading to job losses in the West comes to the fore of political

$4 \quad$ For the argument that as a result, military conflict with the USA is inevitable see Bernstein and Munro (1998), Timperlake (1999), Gertz (2002) and Menges (2005). Mosher (2000) argues that China's centuries old superiority complex is driving s strategy to return itself to its rightful place of global dominance, while Thomas (2001), and Babbin and Timperlake (2006) suggest that China is willing to ally with radical Islam to find a means of overcoming the US. For the view that economic superpower status is here or inevitable, see Weidenbaum and Hughes (1996), Bacani (2003), Overholt (1994) and Murray (1998). 
campaigning as well - particularly during election campaigns in the US. Not only is this understanding firing popular perceptions of China, it is also has considerable purchase in some policy making circles, influencing the adoption of policy towards China. $^{5}$

As noted above, these two visions tend to be dominant, but there are other visions and interpretations. A third broad approach points to a bleak future. For some, China has reached the limits of economic liberalisation within an authoritarian political framework (Pei 2006) and is in a state of crisis (Pei 2002) searching for a miracle (Naím 2003) to avoid the collapse of party rule and perhaps even the Chinese state (Chang 2002). And then there are those who form a fourth broadly defined group who acknowledge that massive changes have taken place in China and that China's global significance has increased, but also point to the developmental problems that remain to be resolved (and in some areas are getting worse), the real social tensions that in some cases have been exacerbated by reform, and the domestic governance challenges for the CCP. ${ }^{6}$ This latter set of writings tends to be academic rather than policy oriented or 'popular' - and increasingly chimes with the research agenda of Chinese researchers, the political-economic stance of the group of Chinese intellectuals who fall under the broad heading of the 'New Left' and the developmental agenda of the fourth generation of Chinese leaders under Hu Jintao and Wen Jiabao. Whilst these understandings have been reflected in the media, ${ }^{7}$ they do not seem to have a significant impact on popular visions of China. Perhaps shades of grey are simply less interesting and less immediate than stark black and white statements and interpretations.

$5 \quad$ If not in the professional China watching foreign policy communities.

$6 \quad$ Examples in chronological order include Bernstein and Lu (2003), Solinger (2005), Croll (2006), Shirk (2007) and Breslin (2007).

For example, in the UK, James Kynge of the Financial Times and Jonathan Watt of the Guardian regularly file stories focusing on those negative impacts of liberalisation. 
This paper has started from the assertion that Chinese power in the global system is exaggerated and not surprisingly, would fit squarely in the last of these four (overly)broad characterizations. But while the intention is indeed in part to provide an antidote to some of the more hyperbolic interpretations of Chinese power, its main intention is to consider why these different interpretations emerge (rather than simply whether they are 'right' or 'wrong'). In trying to explain these varying approaches, we need to concentrate on different sources of information, different audiences and different theoretical approaches. 


\section{$\underline{\text { Explaining Conflicting Visions }}$}

\section{Evidential Contexts}

Although it might sound counterintuitive, the increasing number of foreigners that visit China can actually generate misunderstanding. Visitors typically do not stray far from the newly built modern urban centres, and tend to come into contact with the very real experiences of increasing prosperity but not the equally real experiences of the less well off and the still poor. This is exacerbated by the 'Shanghai phenomenon'. Shanghai has in become the symbol of 'new China' as images of the Pearl TV Tower and the rest of Pudong have become common across the world as representative of not just the vibrant, growing and increasingly rich parts of the Chinese economy, but of China per se.

For those lucky enough to spend much of our time either in China or reading about China, there is a rich pool of evidence to draw on in building understandings. Clearly this is not the case for many visitors to China, and even less so for the general public whose contact with China is overwhelmingly from a distance or 'second hand'. Here what is provided by the media is of course very important, as too is the direct exposure that they have to China or things Chinese. In much of the West, this was until recently pretty largely confined to food. Over the last decade (and particularly over the past five years) the rapid growth of Chinese exports has increased exposure to the idea of China as a global economic force. Quite simply, when people think about 'China', two key words often come first - 'Made In'.

This economic focus has been reinforced by the growth of Chinese outward investment. Though still relatively small by global standards, the purchase of Rover by SAIC in the UK, and the ultimately unsuccessful attempt to buy the US based Unocal oil firm have contributed to the idea that China is becoming a major global 
force. This understanding is reinforced by Chinese 'resource diplomacy' in Latin America and in particular in Africa - whether directly or indirectly, it appears as if 'the Chinese are coming'.

\section{Per capita or Gross? Size really does matter}

There is also the question of how evidence is calculated. Clearly if you take a gross national position, then understandings of China might be rather different than deploying per capita perspectives. Not very much multiplied by 1.3 billion equals an enormous amount. We will return to the importance of per capita perspectives later, but here it is worth acknowledging that the evidence supplied by gross figures really is important. China might be a very low per capita producer of $\mathrm{CO}^{2}$ for example, but sheer numbers mean that the amount of $\mathrm{CO}^{2}$ China produces has massive significance and has an important impact on the global commons.

So using this gross form of evidence is clearly valid in some contexts. The key is to ensure that the most appropriate figures are used in each context. Returning to the environmental example, China is rightly identified as being a major source of $\mathrm{CO}^{2}$ emissions, but if the per capita dimension is not considered, then it might not be possible to think of effective solutions to the problem. For example, if existing conceptions of solutions are just based on dealing with the environmental consequences of wealth which might be expected with this level of emissions (and indeed, does form part of the problem in China), then those environmental issues that are consequences of underdevelopment and indeed even poverty may not be considered. So in alerting policy makers to why China is significant, then the gross size is important - its what's done after the alerting has been achieved that can be problematic if more nuanced approaches built on the reality of contemporary China 
are ignored.

Despite many epistemological differences, not least over the structural basis of international relations, a key strand that links critical post-Marxist and postmodern thinkers is the understanding that theory and knowledge are never politically neutral. The analysis in this paper is more informed by the former than the latter, and in particular the oft cited words of Robert Cox (1981: 128) that 'theory is always for someone and for some purpose'. So the questions that need to be addressed here are for whom and for firstly what purpose are these images of China constructed?

\section{For What Purpose}

\section{China as the Orange Peril?}

One of the reasons that China generates so much interest is that many people are really worried about what the rise of China will mean for them. Furthermore, it is not just that China is changing, but that it is changing so quickly. It is not that long ago that China was, in Napoleon's terms, sleeping and irrelevant for most people in the West. That it has become relatively important so quickly perhaps explains why fear of China is sometimes so exaggerated.

But there is more to it that this. People really are worried about what China represents now, and what China will or might mean for the global order. Here we partly return to the issue of human rights and perceptions of a China that does not adhere to 'our' way of thinking or 'our' way of doing things. And China also represents in one entity two of the big fears of the last century - the challenge to the west from a resurgent and confident Asia, and the challenge to the west of communism. In this respect, the twentieth century challenge to the west is embodied in the construction of a sinophobia against a China that is both the yellow (Asian) and 
red (communist) perils combined, and therefore becomes a new 'orange peril' for the twenty-first century.

\section{Promoting Visions of China in China}

This fear of China is, in some parts at least, a consequence of the way in which the Chinese authorities themselves have constructed a vision of China within China that is then (partially) seen overseas. From the very onset of the reform process in 1978, the Chinese leadership itself has placed a heavy emphasis on growth as an indicator of success, and as a means of gaining legitimacy. In the past at least, Chinese authorities have not shied away from triumphing their success in generating growth and doubling, trebling and quadrupling GDP. Indeed, the target of raising GDP by a factor of X was an often and loudly proclaimed objective of economic reform in the first place. At the international level, the 'Peaceful Rise of China' was developed by Zheng Bijian to assuage concern over China's emerging role by pointing to the positive benefits that China will bring for other economies. ${ }^{8}$ In this respect, GDPism has become a small element of Chinese foreign policy in that arenas such as the Bo'ao Forum for Asia are used to reinforce the message that Chinese growth is a source of regional stability, and therefore it is in other countries' interests to engage the emerging economic power.

The Peaceful Rise discourse highlights a slight schizophrenia in the way that the Chinese authorities project China internationally. On one hand, it not only serves a strategic purpose, but also reflects a growing self confidence about China’s global role. But on the other hand, the Chinese leadership recognises that there has been much more attention on the 'rise' (jueqi 崛起) than the 'peaceful' (heping和平) half of the

$8 \quad$ For an English language explanation of the Peaceful Rise hypothesis, see Zheng (2005). 
slogan. ${ }^{9}$ As a result, it has reinforced the very 'China threat' hypothesis in the US and elsewhere that the 'peaceful rise' was designed to contradict in the first place.

It is true that this message has been tempered when it comes to the international level. The Chinese leadership is quick to point out to the rest of the world that China is still a relatively poor and developing country that should not be expected to shoulder the burdens and obligations of the rich. Witness, for example, the (misguided) attempts to ensure that China was classified as a developing economy during the WTO entry negotiations. ${ }^{10}$ It is also true, that the domestic discourse has changed with the transfer of power to the fourth generation of leadership in the guise of $\mathrm{Hu}$ Jintao and Wen Jiabao. The emphasis on harmonious development (hexie fazhan和谐发展) is based on a recognition that much still remains to be done in terms of promoting development (as opposed to just generating growth) and that the reform experience has not been wholly successful for all. Which brings us to the key issue of the relationship between growth and development, and interpretations of the two.

\section{GDPism}

When viewed with a little more historical distance, the $16^{\text {th }}$ Party Congress may well come to be seen as a key turning point in the evolution of economic reform in China. It is not so much the focus on dealing with the negative consequences of reform that have become associated with the Hu-Wen leadership, though this is clearly important. It's more that for the first time (or more correctly, for the first time for a while), there was a formal recognition that growth and development were not the same thing, and

$9 \quad$ Though Jiang Zemin is widely thought to have rejected the idea of Peaceful Rise when it was first suggested as it was not a powerful enough signal of China's real potential, and underplayed the potential lack of peace in future relations with Taiwan and possibly the United States.

10 Misguided because there are no definitions of 'developing' at the WTO with the actual terms of any new member determined by hard nosed bargaining with existing members rather than by pre-existing templates of duties and obligations. See Breslin (2003). 
that it was time to move the focus of attention from the former to the latter.

There is much that could be said about this domestic change, but in terms of discussing how visions of China are constructed, the emphasis here is on the extent to which external observations of China have tended to either focus on growth rather than development or often to simply use the two terms interchangeably. As growth is primarily a quantitative issue and development more qualitative, this creates a number of misunderstandings (although there are was of 'measuring' development of sorts for example, Human Development Indexes). First, when you start from a very low base, very high growth rates can be generated in relatively poor countries; produce one tractor one year and two the next, and you have 100 per cent growth, but you still only have three tractors. And then, of course, there is the additional questions of which statistics to be used, Purchasing Power Parity (PPP) or atlas method exchange rates, and the already mentioned divergence between per capita and gross figures. Proponents of Chinese wealth and power point to close to double digit growth maintained for over two decades, yet China still remains a relatively poor country in per capita terms coming in at 107th using PPP (US\$6,600 per capita) and 128th (US\$1,740 per capita) using the atlas method in lists of the world's richest countries in per capita terms.

China as a whole may no longer be considered to be 'poor', but is still on ranked as a 'middle income' country at best, and more often as 'lower middle income'. If we take the higher of the per capita income figures using PPP calculations, then China still comes out below Kazakhstan, Namibia, Tonga, Iran, Equatorial Guinea, Thailand, Costa Rica and many others. Yet this is something that is overlooked or perhaps deliberately ignored in the construction of some visions of China as already rich and powerful. And notwithstanding the fact that millions have been brought out 
of poverty in China, Jeffrey Sachs's assertion that 'we can see from China's experience that the end of poverty is absolutely palpable and real in the space of a very few years' (Watts 2006) rather overestimates the situation, and skips over the millions or rural Chinese that are still in poverty, the many millions more that are danger of slipping back into poverty, and the increasing numbers of urban poor (Breslin, 2007: 164-7).

Furthermore, whilst growth is clearly important in providing the wherewithal for development programmes, growth does not necessarily lead to development. The actions of governments in particular, but also other social forces are crucial in ensuring that growth is utilised to create development. And has been argued by Wang Shaoguang and Hu Angang (1993, 2001) China's ability to 'capture' the benefits of growth and use it for developmental projects - China’s 'state capacity' - has been very poor. ${ }^{11}$ There also seems to be a common assumption that China will follow the same path of progression up the value chain and follow the same developmental trajectory of places like South Korea. Of course this might be the case - there is much to suggest that it probably will. But to assume that it is inevitable is simply apolitical and ignores the key role of governments in establishing developmental policies and transferring growth to development. Let's put teleological explanations aside and think of the typical definition of politics as 'the art and science of government'. As Zha (2005) notes, whilst emulating the earlier developmental states of East Asia is highly possible and perhaps probably, emulating the developmental failures of Latin America in the 1970s is not impossible.

In addition, the investment-trade nexus has created growth and boosted China's international profile without generating as much development as the growth

$11 \quad$ Notwithstanding the fiscal reforms of 1994 which at least allowed the central government to get hold of some of those fiscal revenues that had previously remained at the provincial level. See Bahl (1999) and Tsai (2004). 
figures might suggest to the casual observer - an issue we will return to later in this paper.

\section{GDPism and the Neoliberal Project}

It is not surprising that there is such a strong focus on China's growth figures - they really are impressive and as noted above, most people do not have the time and resources to delve beneath the headline figures to think in ore nuanced ways. Related to this, and somewhat tentatively, the focus on GDPism and growth might possibly be related to the desire to promote the neoliberal project. The idea that China has witnessed massive and rapid economic growth by abandoning socialist and embracing market capitalism might represent a misunderstanding of the relationship between state and market in contemporary China. Nevertheless, the understanding that Chinese growth is because 'the masters of China turned towards capitalist enterprise' (Baumol 2002: 3) and participation in the global capitalist economy has become widespread, and the 'success' of capitalism posited in stark contrast to the 'failure' of socialism. Furthermore, this is a message that appears to being heard and acted on in at least some parts of the leadership of other reforming socialist states.

\section{Location, Perspective and Interest}

Where you are writing from (connected to who you are writing for) also appears to be an important determinant of interpretations of China. This is partly because different analytical approaches dominate academic and policy debates in some parts of the world. For example, realist perspectives that are built on assumptions that generate specific understandings are much more dominant in East Asian academia than they are in parts of Europe (we will return to the issue of different theories and approaches 
shortly). It is also because the implications of a changing China are differentially felt across the globe. For example, within East Asia, the growth of the Chinese economy has already had a profound impact on both the structure of the regional political economy, and on the developmental trajectories of individual regional states. The significance of China is clear and present (though whether significance equates to power is a different matter).

So the significance of China is perhaps understandably more real and obvious in East Asia than it is elsewhere. Interestingly, the conception of China as a threat is also much more evident in the US than it is in Europe for example, and the majority of the literature predicting a future Chinese superpower challenging US power emerges from writers based in the US, largely intended to influence US policy makers. In discussing this diversity with colleagues based in North America, it has been suggested that this reflects a lack of understanding of what China will become in Europe. There may have been some truth in this assertion in the past, but China is now very much on political and academic agendas across Europe today. Perhaps a key difference here is the wide scale acceptance in Europe that there is little we can do to change the evolution of china's futures. As a 2000 report from the British House of Parliament on UK relations with China put it, 'the United Kingdom can only hope to influence events in China at the margins' (Foreign Affairs Committee 2000). But in the US, a change in policy towards China could make a difference - hence perhaps the intensity of competition to influence policy makers. ${ }^{12}$

This intensity of discussion in the US has, I suggest, resulted in China being exaggerated to support different stances on Washington's China policy. To

12 Though Kagan (2005) suggests that the US is not as powerful as many make out. He argues that 'the idea that we can manage China's rise is comforting because it gives us a sense of control and mastery, and of paternalistic superiority'. The lesson of history is this will not be possible, and 'we need to understand that the nature of China's rise will be determined largely by the Chinese and not by us'. 
oversimplify the situation, both those who want to contact and those who want to engage China feel the need to talk up China’s importance and significance and power to drown out the arguments of the other side - or at the very least, talk in headline figures and don't consider the totality of the developmental experience within China. Those who see China as a threat - and not militarily - point to China's growing GDP, trade, and in particular trade surplus with the USA and massive foreign currency reserves (more of this later) as evidence of why China should be contained. Those who see China as an opportunity point to similar data to prove just how important it is to engage China to reap the economic rewards for the US.

It is particularly notable that some of the most assertive texts warning of the implications of China's rise for the US are from the same publisher. Gertz's (2002) The China Threat: How the People's Republic Targets America, Timperlake's (1999) Red Dragon Rising: Communist China's Military Threat to America, and Babbin and Timperlake’s (2006) Showdown: Why China Wants War with the United States are all published by Regnery. So too was Triplett's (2004) Rogue State, which argues that 'Communist China, far from being a restraining force on North Korea, is actually the power behind the regime- - how North Korea is, in fact, China's knife wielded against the United States'. ${ }^{13}$ Regnery also published Year of the Rat (Triplett and Timperlake 2000) and Betrayal (Gertz 1999), which both accused President Clinton of selling out US national interests to China. And Regnery do not hide the fact that their books are aimed at what they call 'conservative readers' and that they 'take pride in exposing the liberal bias that so often pervades the 'mainstream' media'. ${ }^{14}$

The annual theatre of the Most Favoured Nation vote may have gone, but China remains an important part of political discourses in the US. Although, other

13 This is taken from the publisher's webpage, www.regnery.com/regnery/040127_rogue.html 14 This is taken from the publisher's webpage, www.regnery.com/about.html 
foreign policy issues ultimately became much more important, relations and particularly economic relations with China did form part of the Democratic campaigns criticisms of George W Bush in late 2003 and 2004. For example, in June 2004, John Kerry responded to a US-China Economic and Security Review Commission Report by criticising the Bush administration for not standing up to Chinese violations of international law - particularly in relation to currency manipulation:

America has lost millions of manufacturing jobs. Just yesterday, we learned that the trade deficit hit a new record. As the trade deficit with China has ballooned, President Bush has stood on the sidelines. He has failed to do anything to effectively address China's predatory currency manipulation, its violation of intellectual property rights and other unfair trade practices that violate its international obligations. ${ }^{15}$

Whether anything would really have changed in a Kerry administration is something that we will never know. George Bush was not the first president to be criticised by opponents over China policy. The Clinton administration was similarly castigated by Republicans for being soft on China and ignoring US economic interests, not least when Bush himself was campaigning for the Presidency. But as outsourcing to China continues from the developed West, and China's economy (and exports from China) continue to grow, it is likely that GDPist perspectives will continue to inform the policy process - particular, but not only, when an election beckons.

Whilst debating what China is (or might become) is perhaps most important in the US, it is far from just a Washington phenomenon. In collecting evidence for the aforementioned UK parliamentary report, a number of key UK based companies http://www.johnkerry.com/pressroom/releases/pr_2004_0615b.html 
constructed a picture of what China might become economically. Without being explicit, the message to government seemed to be that China is too big and good an opportunity to miss, but this opportunity can only be tapped with significant government support. Furthermore, it is a competitive business environment, and if one government doesn't help its companies, then it will lose out to companies in other countries who are getting support from their governments. Such help includes formal technical aid - for example, export credit guarantees - but also 'soft' political support. For some critics, this soft support entails accepting Chinese agendas when it comes to formal political dialogue, and the relegation of political objectives as secondary to economic goals.

\section{Different Theoretical Approaches}

\section{The Failure to Disaggregate the National}

Perspectives of China also differ depending on which theoretical positions are deployed. For example, some analytical approaches simply have no interest in the differential impact of transformation within China, and instead focus on the aggregate picture. For example, some economistic approaches - particularly but not only those that are related to the policy domain - tend to work on national level perspectives that aggregate the economy into a single unit of analysis. The difference between these approaches and those of scholars who consider the domestic dimension in China can be summed up by thinking of the questions that their research starts from. For example, the former would ask, 'is the WTO good for China?’ while the latter would instead ask 'who in China will the WTO be good for, and who might it harm?'.

Focusing the investigation on the aggregate ignores the disaggregated and segregated political reality. To be sure it is easier to consider the nation as a single unit 
of analysis, but political life is not neat and simply, but messy and complex. We have already noted above the definition of politics as 'the art and science of government', but we should remember Harold Lasswell’s (1936) alternative definition of politics as the study of 'who gets what, when and how'.

Whilst the above points to ontological failings (or omissions) of some economistic approaches, there are similar failings and or omissions within some international relations approaches. It is not surprising that 'politics' and 'international relations’ are typically grouped together as a single discipline. The two are usually taught alongside each other in individual academic departments or schools - many of which happily carry the title of 'Politics and International Relations'. But in part at least, different visions of China emerge from the tendency for the two to be isolated as separate and distinct fields of enquiry and the fact that some international relations at least has become 'depoliticised'

For many in the realist tradition, there is an assumed 'national interest' pursued by state actors (and state actors alone) that is unaltered by either the changing ideological preferences of state elites or shifting societal interests and alliances. To be fair, this is something of a blunt characterisation and generalisation of the broad school that we refer to as realism. There are of course realist writers who do consider domestic 'unit level' factors, and how they condition state actors in framing foreign policy. For example, neoclassical realists accept that the domestic level shapes interests and preferences, but believe that states' freedom to act in pursuit of these interests is constrained by the nature of the international system - they have some agency, but this agency is structurally constrained. ${ }^{16}$ Such an approach either explicitly or by implication characterises the work of those country specialists who

$16 \quad$ Gideon Rose's (1998) review of Zakaria (1998), Wohlforth (1993), Schweller (1998), Christensen (1996) and Brown, Lynn-Jones, and Miller (1995) provides a good overview of how neoclassical realism differs from traditional and neo realism. 
study the domestic sources of foreign policy whilst retaining an belief in the overarching principles of realism, and is perhaps best exemplified in Avery Goldstein’s (2005) study of “China’s Grand Strategy”. But for many realists, where national interests come from is for others to consider - the job of an IR scholar is to study the resulting interplay of politics between states, leaving the study of politics within states for others to consider. The diversity and complexity of different opinions, aspirations and interests is often ignored or considered irrelevant, and the language of IR focuses on a single unit of analysis - 'China thinks', 'China says', and 'China wants'.

It is not just realist scholars that tend to treat China as a single actor or entity. Those who write from a liberal tradition should be aware of the need to disaggregate the state and consider on whose behalf state actors are undertaking IR. They should also be aware of the need to move beyond the state as an actor in IR, considering the role of a range of non state actors - but most clearly economic actors. Yet although there is a strong liberal tradition in writings on Chinese IR, the liberalism often only extends to the process and objectives of engaging China - the way in which engaging China can bring it into the international system and socialise it into the dominant western liberal global order. It is also sometimes extended to an understanding of who is engaging China but moving beyond a simply statist understanding (though typically based on an understanding that it is still governments who are the main actors and facilitate engagement). But much of this liberal literature in some ways stops being liberal when it gets to the Chinese side of the equation, still treating the Chinese state as a single straightforward unit of analysis and of Chinese state actors as the actors in IR. The concept of China as the unit of investigation is not always questioned, and the question of which groups and interests Chinese state actors are representing is rarely 
asked. Once again, the failing here is the aggregation of 'China' into a single focus of analysis that is the problem for me

\section{IR analyses of Transnational Economic Networks}

Many realists are also largely unconcerned about economics viewing it as a separate sphere of enquiry to be left to economists to study. However, there are two exceptions to this general rule. First, international economic relations are considered to be important when they embody or reflect power politics between states in a game of mercantilist competition - a subset of politics that can be dealt with by state-to-state diplomatic relations with little attention paid to the role of non-state actors. Second, economic factors are important in establishing conceptions of national power that move beyond traditional security issues - something akin to the Chinese conception of comprehensive national power (总合国力 zonghe guoli). The language of international relations that focuses on the state as actor is echoed in political analyses of actors in international economic relations, which in turn feed into understandings of China's rising economic power - 'China dominates in the production of', 'China leads the way in exports of', 'China is the leading producer of', and so on (Hale and Hale 2003). ${ }^{17}$ Here international economic relations are typically viewed in terms of interactions between nation states (or equivalents1). As with those economistic approaches noted above, the domestic economy is aggregated into a single unit -

\section{'China'.}

Not only does this approach fail to disaggregate 'China' itself geographically, sectorally, and in all the ways already mentioned above - it also

17 It's a bit unfair to cite Hale and Hale as an example here as they acknowledge that China's 'leading' position is largely a result of foreign investment. But this piece remains a good example - partly because it largely considers China as a single unit of analysis, and also partly because articles in Foreign Affairs are read by a wider audience than articles in purely academic journals. 
makes a fundamental error. It tends to treat international economic relations as exactly that - inter national (between nations) - whereas the reality of trade and investment patterns does not conform to conceptions of two states (or even more states) doing things to each other when it comes to trade and investment. This conceptual error is compounded by the evidential context used to support such inter national approaches and then people look at these misleading statistics and develop misled conclusions about 'Chinese power' in the production of these goods. Trade and investment figures are bilateral in nature, displaying an interaction that at best is only a snapshot of what is happening at one small part of a much longer chain of interactions. Moreover, the penultimate territory in which production takes place is typically considered to be the exporter and credited with the resulting trade surplus with the final territory (the market). Notwithstanding regulations on rules of origin in calculating trade figures, it is still the case that 100 per cent of the value of an import to the USA can be credited to China, ever if the majority of that value was originally imported to China from other territories. Although Chinese companies do seem to be occupying more of the product chain, historically at least, exports from Foreign Invested Enterprises have been massively dependent on imported components - primarily from South East Asia, Taiwan and Japan but also from the US and Europe.

China as a whole is clearly benefiting from its position in the global economy - but not as much as appears at first sight to the casual observer looking at the aggregate figures (and certainly not as much as those who point to the inevitable China challenge to world order often suggest). Others have also benefited significantly from what has happened in China. For example, consumers in the west are now paying less in actual pounds, dollars and euros (let alone real terms) for goods than they were five or even 10 years ago. And some of the main beneficiaries 
of economic growth in China have been the companies that have closed their old factories in the expensive developed world and moved their production to China (and elsewhere) - even if this has resulted in job losses in the west that are often blamed on this thing called 'China'.

Of course, it's entirely understandable that international relations scholars focus on relations between nations. But if we want to keep nations as the unit of analysis, then we need to be much more nuanced and consider how post-fordist production process result in a highly fragmented process spanning many different countries. ${ }^{18}$ Is it China that is leading the way, for example, in the production of TVs and computers or even training shoes, or is china still largely the conduit through which money and technology from other countries is processed? Is China the generator of global growth, or the conduit through which other interests outside China maintain dominant positions on global trade and investment hierarchies? Perhaps after all, the search for the location of power in nations is misplaced, and we should instead be considering key global actors such as Walmart and Nike in our search for the location of global power.

\section{Conclusions - GDPism, Domestic Politics, and International Relations}

The suggestion that growth should not simply be equated with development would come as no surprise whatsoever to the Chinese leadership. Indeed, the period between the $16^{\text {th }}$ and $17^{\text {th }}$ party congresses in 2002 and 2007 respectively witnessed a key shift from a growth to a developmental paradigm. Clearly, generating growth is important but its what is done with that growth that generates development (or not as the case may be). The evidence of the previous paradigm under Jiang Zemin and Zhu Rongji

18 That much more of this investment has its origins in the US that the bilateral investment figures can show is an entire study in itself - and forms part of Breslin (2007: 106-30). 
was that unevenly distributed growth had not only exacerbated inequality, but had also failed to reduce poverty as much as might have been expected, and had done little to ensure the adequate provision of health education and welfare (particularly in rural areas). Additionally for Yu Yongding (2006), the predominance of processing assembly in Chinese trade has meant that export growth has had a remarkably minor impact in terms of promoting domestic industrial upgrading and laying the foundations for a more sustainable and developmentally orientated economic future. Whilst the Chinese media takes care to show the party as a successful and modernising organisation, this vision of China is balanced with a recognition of the many developmental objectives that remain to be attained, and the crucial role that party and state officials have to play at all levels to reach these goals.

So a key conclusion of this paper is that the study of china's global role should be re-embedded in the study of the domestic. At the very least, those understandings/predictions that ignore the domestic (or assume a continued stable political position with the only challenge a democratic one) should acknowledge that they cannot even start to understand how the social problems identified by Chinese scholars and the current Chinese leadership create significant constraints on global ambitions and global potentials. In addition, it is simply apolitical to simply assume that China will follow expected developmental trajectories irrespective of political action by the government and other actors within China.

A second conclusion is that misunderstandings or unrealistic evaluations of Chinese power are partly deliberately constructed by interested parties in an attempt to influence policy - and that these evaluations have a real impact on the construction of other countries' policies towards China. So in some respects, whether China really does possess such power or not is irrelevant - if it is assumed to be powerful now or 
soon, and policies developed on the understanding that China has that power now, then Chinese power is bestowed on it from others.

The third conclusion is that how China is perceived depends very much on the epistemologies and approaches deployed. Most clearly, at least some of the exaggerated understandings of China as inevitable superpower soon and engine of the global economy now are mistaken because of the way that observers conceive of international relations in general, and international economic relations in particular. The aggregation of China into a single unit for analysis and the focus on economic relations between nation states may generate simple and easily comprehended conclusions about the nature of power in world of nation states. But if the reality of production, finance and trade does not simply map onto a state centric conception of inter-national relations, then focussing on the latter cannot explain the future. Ease of comprehension is clearly laudable - but not if it is only achieved by ignoring the messy complexity of multiple transactions in a post-fordist global capitalist world.

\section{References}

Alden, E. and Harding, J. (2004) 'Bush's China Stance Hands Kerry a Big Stick', Financial Times, $30^{\text {th }}$ April.

Babbin, J. and Timperlake, E. (2006) Showdown: Why China Wants War with the United States (Washington: Regnery).

Bacani, C. (2003) The China Investor: Getting Rich with the Next Superpower (Indianapolis: John Wiley).

Bahl, R. (1999) Fiscal Policy in China: Taxation and Intergovernmental Fiscal Relations (Ann Arbor: University of Michigan Press).

Barboza, D. (2003) ‘Textile Industry Seeks Trade Limits on Chinese’, New York Times, $25^{\text {th }}$ July.

Baumol, J. (2002) The Free-market Innovation Machine: Analyzing the Growth Miracle of Capitalism (Princeton: Princeton University Press). 
Bernstein, R. and Munro, R. (1998) The Coming Conflict with China (New York: Vintage).

Bernstein, T and Lu Xiaobo (2003) Taxation Without Representation in Contemporary Rural China (Cambridge: Cambridge University Press).

Breslin, S. (2003) "Reforming China's Embedded Socialist Compromise: China and the WTO” in Global Change, 15 (3): 213-229.

Breslin, S. (2004) 'Beyond Diplomacy? UK Relations With China Since 1997', British Journal of Politics and International Relations, 6 (3): 409-425.

Breslin, S. (2007) China and the Global Political Economy (Basingstoke: PalgraveMacmillan).

Brown, M., Lynn-Jones, S. and Miller, S (eds) (1995) The Perils of Anarchy: Contemporary Realism and International Security (Cambridge: MIT Press).

Chang, G. (2002) The Coming Collapse of China (New York: Random House).

Christensen, T. (1996) Useful Adversaries: Grand Strategy, Domestic Mobilization, and Sino-American Conflict, 1947-1958 (Princeton: Princeton University Press).

Cox, R. (1981) 'Social Forces, States and World Orders', Millennium: Journal of International Studies, 10 (2): 126-55.

Croll, E. (2006) China's New Consumers (London: Routledge).

Engels, F. (1970) 'Socialism: Utopian and Scientific' in Karl Marx and Fredrick Engels Selected Works, Volume 3 (London: Progress): 95 -151.

Foreign Affairs Committee (2000) Tenth Report, Session 1999-2000: Relations with the People's Republic of China (Norwich: Her Majesty's Stationary Office).

Gertz, W. (2002) The China Threat: How the People's Republic Targets America (Washington: Regnery).

Gertz, W. (1999) Betrayal : How the Clinton Administration Undermined American Security (Washington: Regnery).

Goldstein, A. (2005) Rising to the Challenge: China's Grand Strategy and International Security (Stanford: Stanford University Press).

Hale, D. and Hale, L. (2003) 'China Takes Off’, Foreign Affairs, 82 (6):36-53.

Kagan, R. (2005) 'The Illusion of 'Managing' China', Washington Post, $15^{\text {th }}$ May.

Lasswell, H. (1936) Politics: Who Gets What, When, How (New York: McGraw-Hill).

Lemoine, Francoise and Unal-Kesenci, Deniz (2004) 'Assembly Trade and 
Technology Transfer: The Case of China’, World Development, 32 (5): 829-50.

Menges, C. (2005) China: The Gathering Threat (Nashville: Thomas Nelson).

Mosher, S. (2000) Hegemon: China's Plan to Dominate Asia and the World (New York: Encounter).

Murray, G. (1998) China: The Next Superpower: Dilemmas in Change and Continuity (Basingstoke: Palgrave-Macmillan).

Naím, M. (2003) ‘Only a Miracle Can Save China’, Financial Times, $15^{\text {th }}$ September.

Overholt, W. (1994) The Rise of China: How Economic Reform is Creating a New Superpower (London: Norton).

Pei Minxin (2002) ‘China’s Governance Crisis’, Foreign Affairs, (SeptemberOctober): 96-109.

Pei Minxin (2006) China’s Trapped Transition: The Limits of Developmental Autocracy (Cambridge: Harvard University Press).

Rose, G. (1998) 'Neoclassical Realism and Theories of Foreign Policy', World Politics, 51 (1): 144-172.

Schweller, R. (1998) Deadly Imbalances: Tripolarity and Hitler's Strategy of World Conquest (New York: Columbia University Press).

Shirk, S. (2007) Fragile Superpower: How China's Internal Politics Could Derail Its Peaceful Rise (New York: Oxford University Press).

Solinger, D. (2005) 'The Creation of a New Underclass in China and its Implications', University of California, Irvine Center for the Study of Democracy Working Paper, No. 05’10.

Strange, S. (1996) The Retreat of the State (Cambridge: Cambridge University Press).

Thomas, G. (2001) Seeds of Fire: China and the Story Behind the Attack on America (Tempe: Dandelion).

Timperlake, E. (1999) Red Dragon Rising: Communist China's Military Threat to America (Washington: Regnery).

Triplett, W. (2004) Rogue State (Washington: Regnery).

Tsai, K. (2004) 'Off Balance: The Unintended Consequences of Fiscal Federalism in China’, Journal of Chinese Political Science, 9 (1): 7-26.

Triplett, W. and Timperlake, E. (2000) Year of the Rat (Washington: Regnery).

Vidal, J. (2006) 'How World's Biggest Ship is Delivering our Christmas - All the Way 
from China: Huge Movement of Goods Reflects Dominance of New Manufacturing Superpower', The Guardian, $30^{\text {th }}$ October.

Wang Shaoguang and Hu Angagng (2001) The Chinese Economy in Crisis: State Capacity and Tax Reform (Armonk: East Gate).

Wang Shaoguang and Hu Angang (1993) Zhongguo Guojia Nengli Baogu (Report on China’s State Capacity) (Shenyang: Liaoning People’s Press).

Watts, J. (2006) 'Be Here Now', The Guardian, 26 ${ }^{\text {th }}$ August.

Weidenbaum, M. and Hughes, S. (1996) The Bamboo Network: How Expatriate Chinese Entrepreneurs Are Creating a New Economic Superpower in Asia (New York: Simon and Schuster).

Wohlforth, W. (1993) The Elusive Balance: Power and Perceptions during the Cold War (Ithaca: Cornell University Press).

Yu Yongding (2006) ‘A Look at China's Readjustment of Mode of Economic Growth', People's Daily (online edition), $22^{\text {nd }}$ August.

Zakaria, F. (1998) From Wealth to Power: The Unusual Origins of America's World Role (Princeton: Princeton University Press).

Zha Daojiong (2005) 'Comment: Can China Rise?', Review of International Studies, 31 (4): 775-785.

Zheng Bijian (2005) 'China's 'Peaceful Rise' to Great Power Status', Foreign Affairs, 84 (5): 18-24. 